Risiko, Return Investasi dan Kinerja Saham (Studi Perbandingan Volatilitas Harga Saham Syariah dan Konvensional Dengan Menggunakan Model Garch)

\title{
Kiki Azakia
}

Dosen Universitas Bina Insan. E-mail: azakia19@gmail.com

\section{Ach Faqih Supandi}

Dosen Universitas Islam Jember E-Mail: achfaqih795@gmail.com

\section{Kurniawan Ramadhani}

Mahasiswa Fakultas Ekonomi Islam IAIN Jember. E-mail: dhanisantoso333@gmail.com

\section{Feri Umar Dani}

Mahasiswa Fakultas Ekonomi Islam IAIN Jember. E-mail: feri.iref05@gmail.com

\section{ARTICLE INFO}

Kata Kunci:
Risiko, Return, Kinerja,
Volatilitas, Saham
Syariah, Saham
Konvensional dan
GARCH.

\section{Cara Sitasi:}

Azakia, Kiki, Ach Faqih Supandi, Kurniawan Ramadhani, Feri Umar Dani "Risiko, Return Investasi Dan Kinerja Saham (Studi Perbandingan Volatilitas Harga Saham Syariah Dan Konvensional Dengan Menggunakan Model Garch)." At-Taradhi: Jurnal Studi Ekonomi 11 , no. 2 (2020): 135150.

\begin{abstract}
The purpose of this study was to see the differences in return, risk and stock performance in a conventional and Islamic stock company. In addition, it will also compare the volatility of Islamic and conventional stock prices using the GARCH model. Meanwhile, this study uses a quantitative method which is a cross section which is taken from the closing stock price of a company listed on JII and LQ in the 48 period 2016-2018. The method for analyzing using the Mann Whitney test. To find out the volatility in the company's stock price using the GARCH estimation model. The results of this study are that the $M A P E$ of Islamic companies is smaller than the MAPE of conventional companies, namely 2.019305 and 2.522283. So it can be concluded that Islamic stock companies are lower than conventional stock companies
\end{abstract}

Tujuan dari penelitian ini adalah untuk melihat perbedan yang terdapat pada Return, Resiko dan kinerja saham pada sebuah perusahaan saham syariah dan konvensional. Selain itu juga akan membandingkan antara volatilitas harga saham syariah dan konvensional dengan menggunakan model GARCH. Sedangkan metodologi pada penelitian ini menggunkan metode kuantitatif yang sifatnya cross section yang diambil dari penutupan harga saham sebuah peruasahaan yang terdapat pada JII dan LQ pada 48 periode 2016-2018. Metode untuk menganalisis menggunakan uji Mann Whitney. Untuk mengetahui Volatilitas pada harga saham perusahaan menggunakan model estimasi GARCH. Hasil dari penelitian ini adalah MAPE perusahaan syariah lebih kecil dari pada MAPE perusahaan konvensional yakni pada angka 2.019305dan 2.522283. sehingga dapat dipulkan bahwa perusahaan saham syariah lebih rendah dari pada perusahaan saham konvensional. 


\section{Pendahuluan}

Pasar modal adalah salah satu pasar perdagangan saham serta merupakan sarana bagi perusahaan untuk mendapatkan banyak dana dengan menjual belikan saham kepada masyarakat. Investasi pada pasar modal memiliki konsep tersendiri sehingga dapat menarik para pelaku usaha makro untuk dapat melakukan investasi agar dapat memilih dengan bebas jumlah sekuritas yang diperdangankan dalam dunia pasar modal. Indonesia adalah salah satu negara yang masyarakatnya mayoritas beragama Islam yang memegang teguh asas-asas syariat Islam, maka sangat dibutuhkan pasar modal yang sama sekali tidak bertentangan dengan syariat Islam sehingga sesuai dengan praktek kehidupan sehariharinya. Kebutuhan tersebut dapat memicu munculnya saham yang sesuai dengan syariah yang semua itu dapat terhimpun dalam Jakarta Islamic Indeks (JII). ${ }^{1}$ Maka dengan demikian, hal tersebut diprediksikan akan dapat menajadi wadah dan sarana prasarana bagi para investor muslim untuk menambahkan modalnya pada pasar modal syariah. Berikut ini merupakan tabel pertumbuhan saham syariah dan juga saham konvensional yang dapat dilihat sebagai berikut:

\section{Tabel 1. Pertumbuhan Transaksi Saham Syariah dan Saham Konvensional periode} 2011-2016

\begin{tabular}{ccc}
\hline Indikator & Saham Syariah & Saham Konvensional \\
\hline Volume & $167,2 \%$ & $130 \%$ \\
\hline Nilai & $70,7 \%$ & $25,4 \%$ \\
\hline Frekuensi & $185,7 \%$ & $160,7 \%$ \\
\hline
\end{tabular}

Sumber: www.idx.co.id

Berdasarkan pada kondisi perekonomian yang masih belum stabil, maka para investor menjadi lebih selektif dalam menginvestasikan dananya pada setiap perusahaan. Kuputusan para investor tersebut berdasarkan pada Risk dan Return yang merupakan dua hal yang penting dalam dunia investasi. Pengertian return menurut Jones adalah merupakan sebuah imbalan kepada para investor yang sudah memberikan kepercayaan modal dengan berinvestasi (George 2002). Sedangkan Risiko menurut Keown adalah suatu kemungkinan pengambilan yang akan berbeda dari tingkat pengembalian yang telah diharapkan. $^{2}$ Dalam melakukan investasi yang perlu dilakukan adalah tingkat pengembalian (expected rate of return), tingkat risiko (rate of risk) dan ketersediaan dana yang akan diinvestasikan. ${ }^{3}$

Apabila pada saat tingkat pengembalian (Return) dari berbagai saham relative sama, maka bursa saham yang terendah secara otomatis akan terpilih menjadi saham yang lebih baik, begitu juga dengan sebaliknya, jika tingkat risikonya relatif sama maka saham denga tingkat pengembalian (Return) dengan sendirinya akan terpilih menjadi saham terbaik pada tingkatannya. Kenaikan harga saham akan mengakibatkan pada kinerja investasi. Sedangkan pada harga saha sendiri dapat ditentukan secara lelang continue, dan pada pasar saham akan dapat terbentuk dengan mekanisme permintaan dan penawaran pada

\footnotetext{
1 Ali Maskur, "Volatilitas harga saham antara saham konvensional dan syariah," Dinamika Kenangan dan Perbankan 1, no. 2 (2009): 82-94.

${ }^{2}$ David F Scott, Basic Financial Management. (Upper Saddle River: Prentice Hall, 1999), 50.

${ }^{3}$ Abdul Hakim, Analisis Investasi Edisi Revisi II (Jakarta: Salemba Empat, 2005), 45.
} 
setiap pasar modal. ${ }^{4}$ Harga saham adalah merupakan suatu indikator dalam pengelolaan sebuah perusahaan sehingga dapat menghasilakan keuntungan yang memuaskan bagi para investor yang cukup rasional. Menurut hasil penelitian Febrianti (2017) terdapat pebedaan yang sangat signifikan dalam regulasi sahan pada perusahaan baik yariah ataupun konvensional. Hal tersebut dapat dianalisis dari tingkat kenaikan harga saham konvensional yang elatif meningkat atau mengalami kenaikan harga, akan tetapi hal demikian biasa akan diiringi dengan penurunan harga saham secara signifikan juga. Berbed dengan harga saham syariah yang relatif stabil dan dapat diprediksi sebelumnya, sehingga para investor merasa aman atau tidak was-was jika sewaktu-waktu mengali penurunan harga. Sehingga risiko kerugian akan semakin minimalis.

Pergantian return dari suatu index harga saham memiliki ketidak pastian, terkadang bersifat positif dan negatif. Sehingga untuk menditeksi sebuah kepastian yang akan terjadi maka perlu digunakanlah sebuah metode untuk mengukur yang sering disebut volatilitas, volatilitas sendiri artinya Conditional variance (varian dinamik) dari sebuah asset. ${ }^{5}$

Dalam pengambilan keputusan pada investasi sangat dibutuhkan sebuah analisis sehingga dapat mengambil sebuah keputusan yang optimal, salah satu analisis yang sangat berpengaruh dalam pengambilan keputusan yakni dengan analisis volatilitas, analisis tersebut sangatlah berguna untun membentuk portopolio, Manajemen Risiko serta pembentukan harga untuk melakukan investasinya. Contoh apabila volatilitas tinggi maka para investor akan menjual semua asset dan dapat dipastikan akan meninggalkan pasar modal demi untuk meminimalkan sebuah risiko yang akan di dapatkannya. ${ }^{6}$

Sebuah penelitian juga menyampaikan bahwa volatilitas saham syariah dan konvensional sangat tinggi dan meningkat secara terus menerus (persistent). Apabila sebuah volatilitas sangat tinggi maka risiko yang akan terjadi akan sangat sulit untuk di prediksi. Oleh karena itu analisis volatilitas pada harga saham yang sedang terjadi merupakan hal yang cukup penting untuk digunakan oleh para investor agar pengambilan keputusan bisa terarah untuk proses selanjutnya. ${ }^{7}$ Selain itu para investor juga dengan menginvestasikan modalnya sangat mengharapkan keuntungan/imbalan yang cukup tingga dengan berinvestasi serta meminimalkan tingkat risiko yang cukup rendah. Pemilihan model GARCH dalam pengujian volatilitas banyak dipergunakan oleh beberapa peneliti yang diantaranya adalah Ratih (2008) ${ }^{8}$, Ali (2009). ${ }^{9}$ Sehingga mereka berpendapat bahwa menggunakan model GARCH dalam menganalisis volatilitas sangatlah cocok untuk melihat volatilitas data keuangan perusahaan.

\footnotetext{
${ }^{4}$ Iswi Hariyani dan R. Serfianto Dibyo Purnomo, "Buku Pintar Hukum Bisnis Pasar Modal Strategi Tepat Investasi Saham," Obligasi, Waran, Right, Opsi, Reksadana, \& Produk Pasar Modal Syariah, Transmedia Pustaka, Jakarta, 2010, 67.

5 Herni Ruliatul Kasanah dan Saparila Worokinasih, “Analisis Perbandingan Return dan Risk Saham Syariah dengan Saham Konvensional (Studi pada Jakarta Islamic Index (JII) dan IDX30 Periode 20142016)," Jurnal Administrasi Bisnis 58, no. 2 (2018): 46-55.

${ }^{6}$ Tandelilin Eduardus, "Portofolio dan Investasi teori dan aplikasi," Yogyakarta: Kanisius, 2010, 67.

7 Ajeng Gama Rosyida dan Imron Mawardi, "Perbandingan Tingkat Pengembalian (Return), Risiko dan Koefisien Variasi pada Saham Syariah dan Saham Non Syariah di Bursa Efek Indonesia (BEI) Periode 2011-2013," Jurnal Ekonomi Syariah Teori dan Terapan 2, no. 4 (2015).

8 Ratih Puspitasari dan Defani Pramesti, “Analisis Resiko Dan Tingkat Pengembalian Saham Terhadap Portofolio Optimal Saham (Studi Kasus Pada 8 Saham Dari LQ-45),” 1 Oktober 2011.
}

${ }^{9}$ Maskur, "Volatilitas harga saham antara saham konvensional dan syariah." 
Berdasarkan pada penjelasan diatas maka penulis dapat presentasikan jika para investor muslim memiliki sebuah tantangan yang baru yakni mampukah para investor muslim bersaing dengan investasi saham konvensional. Atau lebih pada risikonya lebih besar dari pada saham syariah. Dari beberapa fenomina yang telah dipaparkan diatas maka penulis berrinisiatif untuk membandngkan seberapa besar perbedaan yang terdapat dalam Risk dan Return serta harga saham antara saham syariah dan saham konvensional berdasarkan pada analisis volatilitas sehingga para investor tidak merasakan keraguan sama sekali untuk melakukan investasi pada saham saham syariah.

Berdasarkan pada deskripsi diatas maka penulis disini akan mengungkap beberapa fakta berdasarkan beberapa metode dalam penelitian ini sehingga penulis dapat membandingkan saham syariah dan konvensional. Oleh karena itu penulis mengambil judul Risiko, Return Investasi dan Kinerja Saham (Studi Perbandingan Harga Saham Syariah dan Konvensional Dengan Menggunakan Model GARCH)

\section{Tinjauan Pustaka}

Rosyida, Ajeng Gama. 2015. Perbandingan Tingkat Pengembalian (Return), Resiko dan Koefisien Variasi pada Saham Syariah dan Saham Non Syariah di Bursa Efek Indonesia (BEI) Periode 20112013 Penelitian ini dilakukan dengan menggunakan pendekatan kuantitatif, yaitu penelitian yang menitikberatkan pada pengujian hipotesis, mengukur variabel yang sedang diteliti dan akan menghasilkan kesimpulan yang dapat digeneralisasikan, serta menggunakan alat bantu statistik. menghasilkan kesimpulan bahwa tidak terdapat perbedaan signifikan antara tingkat return dari saham syariah dan saham non syariah di Bursa Efek Indonesia (BEI) dengan tingkat signifikansi sebesar 5\% $(\alpha=0,05)$.

Nurdin, Ade Ali. 2009. Perbandingan Kinerja Portofolio Optimal Saham-Saham Unggulan Berbasis Syariah dengan Saham-Saham Unggulan Berbasis Konvensional di Bursa Efek Indonesia, Metode penelitian yang digunakan dalam penelitian adalah penelitian deskriptif yaitu penelitian dilakukan mulai dari mengumpulkan data, mengolah data, menganalisis data sehingga menghasilkan gambaran yang jelas tentang pokok permasalahan dengan interpretasi hasil pengujian hipotesis. Penelitian ini tidak bermaksud untuk mencari pengaruh atau hubungan sebab akibat, tetapi hanya untuk membandingkan apakah suatu variable yang memperoleh perlakuan berbeda menunjukan adanya suatu perbedaan yang signifikan, Hasil analisis terhadap saham - saham syariah dan konvensional yang dilakukan berdasarkan model Roy's Creation menghasilkan portofolio optimal untuk saham syariah sebanyak 18 saham dari 26 jenis saham syariah, dengan nilai nilai portofolio optimal tertinggi sebesar 0149,909, yaitu saham Indosat Tbk, dan nilai portofolio optimal terendah dihasilkan saham PP London Sumatera Tbk sebesar 1,823356. Adapun untuk saham-saham konvensional yang berjumlah 12, yang menghasilkan portofolio optimal sebanyak 7 saham dengan nilai portofolio optimal tertinggi adalah saham Bank Mandiri Tbk sebesar 91,16178 dan nilai portofolio optimal terendah saham Bank Niaga Tbk sebesar 6,07256. Model Roy's Creation menentuken portofolio optimal dengan membandingkan expected return portofolio dengan Reward to Variabelity ratio dimana risiko diukur dengan standar deviasi portofolio.

Sulasih.2008. Analisis Resiko dan Tingkat Pengembalian pada Portofolio Optimal Saham LQ-45 Di Bursa Efek, Penelitian ini merupakan penelitian deskriptif yang didasarkan atas survei terhadap objek penelitian. Penelitian dilakukan dengan tujuan untuk membentuk 
portofolio optimal saham-saham yang terdaftar di Bursa Efek Indonesia dengan menggunakan model indeks tunggal. Hasil dari pembasasan jurnal ini adalah tersusunnya sebuah portofolio saham yang terdiri dari empat saham, yaitu ASRI (48,72\%), INDF $(28,24 \%)$, BBNI $(16,32 \%)$, dan BKSL (6.71\%). Hasil pengujian hipotesis pertama menunjukkan bahwa ada perbedaan dalam return saham dari portofolio candidate dibandingkan dengan portofolio noncandidate. Hasil pengujian hipotesis kedua menunjukkan bahwa tidak ada perbedaan dalam risiko saham yang termasuk dalam portofolio candidate dibandingkan dengan portofolio non candidat

Persamaan dalam penelitian ini sama sama menggunakan metode kuantitatif serta pada pendeskripsian dari analisa sebuah pelaporan dan membandingkan kekuatan pada indeks saham konvensional dan saham syariah dalam analisa stastistik

Perbedaan peneliian ini pada model analia yang digunakan oleh peneliti menggunakan model standar baku dan simpanagan baku dalam mengnalisa data yang telah diketahui dari indikator indeks saham

\section{Risiko}

Menurut Tandelilin, Risiko merupakan kemungkinan perbedaan antara return aktual dengan return yang diharapkan. Semakin besar kemungkinan perbedaannya, berarti semakin besar resiko investasi tersebut. ${ }^{10}$ Pengertian lain dari resiko yang dikemukakan oleh Gitman (2003) "Risk is chance of financial loss or more formalyy, the variability of return associated with given assets." Artinya: Bahwa risiko adalah kemungkinan kerugian atau lebih formal diartikan sebagai vaiabilitas pengembalian yang terkait dengan aset yang diserahkan. Hartono menyebutkan bahwa risik adalah kemungkinan menyimpangnya keuntungan yang sesungguhnya (actual return) dari tingkat keuntungan yang diharapkan (expected return). ${ }^{11}$

Risiko adalah merupakan salah satu faktor yang cukup penting dalam berinvestasi, karena pada setiap pilihan berinvestasi akan menghadapi sebuah risiko baik itu kecil ataupun besar. Para investor sangatlah berhati-hati dengan tingkat risiko karena hal tersebut akan mempengaruhi terhadap tingkat keuntungan yang akan didapat dalam berinvestasi. Risiko merupakan variabilitas return realisasi terhadap return yang diharapkan, resiko selalu berhubungan dengan ketidakpastian. Para pemodal dalam melakukan investasi tidak akan dapat mengetahui nilai return dimasa yang akan datang, sehingga dalam melakukan investasi para pemodal/ investor akan menghindar dari tingkat risiko yang cukup tinggi serta menanggungnya meskipun para investor tidak akan terbebas dari sebuah risiko.

\section{Return}

Return saham dapat didefinisikan bedagai pendapatan (income) yang diperoleh dari investasi saham selama periode investasi perjumlah dana yang diinvestasikan dalam bentuk saham (Boediono, 2000). Terdapat dua komponen yang diperoleh return pada perusahaan saham yakni Capital gain (loss) dan Yield. Capital gain (loss) adalah perselisihan harga yang sekarang dengan periode sebelumnya. Yield merupakan komponen return merupakan aliran arus kas atau sebuah pendapatan tang dihasilkan

\footnotetext{
${ }^{10}$ Eduardus, "Portofolio dan Investasi teori dan aplikasi."

11 Anwar Ramli, "Risk dan return saham perusahaan industri barang konsumsi di bursa efek Indonesia," Jurnal Aplikasi Manajemen 8, no. 4 (2010): 1090-1097.
} 
secara periodik dari setiap investasi. Dalam hal saham, yield diperlihatkan dari besarnya dividen yang diperoleh. Jogianto (2013) berpandapat bahwa Return kedalam dua bagian yakni return realisasi (realized return) dan return ekspektasian (expected return) Return realisasian merupakan return yang terjadi, return ini sangatlah penting untuk diperhatikan karena sering dipergunakan sebagai salah satu kinerja dari setiap perusahaan. Return realisasian atau return historis juga berguna sebagai dasar penentuan return expektasian dan resiko dimasa yang akan datang. Sedangkan, return ekspektasian merupakan tingkat pengembalian yang diharapkan yang akan diperoleh investor di masa yang akan datang. Berbeda dengan return realisasian yang sifatnya sudah terjadi, return expektasian sifatnya belum terjadi. ${ }^{12}$

Dalam konteks manajemen investasi, pengambilan (return) merupakan imbalan yang dapat diperoleh dari kegiatan investasi. Pengembalian ini dibedakan menjadi dua, yaitu pengembalian yang telah terjadi (actual return) yang dihitung berdasarkan data historis, dan pengembalian yang diharapkan (expected return-ER) akan diperoleh investor di masa depan.

\section{Saham}

KBBI menyebutkan bahwa saham adalah satuan nilai atau pembukuan dalam berbagai instrument financial yang mengacu pada bagian kepemilikan sebuah perusahaan. Pengertian lain menerjemahkan saham adalah sebagai tanda kepemilikan seseorang terhadap suatu perusahaan atau perseroan terbatas, pada dasarnya saham tersebut berbentuk lemabaran kertas yang hal tersebut menunjukkan bahwa seseorang tersebut adalah pemilik sah dari saham tersebut atau bisa juga dikatakan dengan surat berharga dan porsi kepemilikan tersebut ditentukan seberapa besar modal yang ditanamkan pada saham terebut. ${ }^{13}$

Saham berasal dari bahasa arab sahama yang berarti bagian. Sedangkan istilah saham adalah penanaman modal terhadap suatu perusahaan atau memasukkan modal terhadap perusahaan perorangan yang membutuhkan modal cukup banyak. Dengan kata lain "sebuah cek yang dikeluarkan oleh syirkah yang mana si penanam saham mempunyai hak didalamnya atau "sebuah kepemilikan hak didalamnya atau "sebuah kepemilikan hak seorang penanam saham terhadap sebagian modal syirkah tertentu". Sedangkan pengertian saham secara umum dan sederhana adalah surat berharga yang dapat dibeli atau dijual oleh perorangan atau lembaga dipasar tempat surat tersebut diperjual belikan. ${ }^{14}$

Menurut Fatwa Dewan Syariah Nasional (DSN) Majelis Ulama Indonesia (MUI) No.40/DSN-MUI/X/2003 tentang Pasar Modal dan Pedoman Umum Penerapan Prinsip Syariah di Bidang Pasar Modal, mendefinisikan saham syariah merupakan bukti kepemilikan atas suatu perusahaan yang memenuhi kriteria tidak bertentangan dengan prinsip- prinsip syariah. Berdasarkan peraturan Bapepam-LK (OJK) No. IX.A.13 tentang Penerbitan Efek Syariah, khususnya ayat 1.a.3, yang dimaksudkan dengan efek syariah adalah efek sebagaimana dimaksudkan kedalam undang- undang pasar modal dan peraturan pelaksanaan mengenai: akad, cara, dan kegiatan usaha

\footnotetext{
${ }^{12}$ Hartono M. Jogiyanto, “Teori portofolio dan analisis investasi,” Edisi Ketujuh. BPFE. Yogyakarta, 2010.

${ }_{13}$ Adrian Sutedi, Pasar modal syariab: sarana investasi kenangan berdasarkan prinsip syariah (Rawamangun, Jakarta: Sinar Grafika, 2011), 40.

${ }^{14}$ Wiku Suryomurti, “Super Cerdas Investasi Syariah,” Jakarta: Qultum Media, 2011, 50.
} 
yang menjadi landasan penerbitannya tidak bertentangan dengan prinsip-prinsip syariah dipasar modal. ${ }^{15} \mathrm{Hal}$ ini mengartikan bahwa saham syariah merupakan surat berharga yang mempresentasikan penyertaan modal kedalam perusahaan yang tidak bertentangan dengan syariat Islam.

\section{Kinerja Saham}

Istilah kinerja atau performance yang biasa dikaitkan pada kondisi keuangan sebuah perusahaan, kinerja yang merupakan suatu hal yang sangat penting dalam pencapaian sebuah perusahaan, karena kinerja merupakan analisa sebuah perusahaan dalam mengemban pengelolaan dan mengalokasikan sumber dayanya.

Salah satu bagian dari proses analisis skuritas dam investasi adalah penilaian dalam kinerja saham baik syariah maupun konvensional. Penilaian tersebut juga termasuk menilai perusahaan yang menerbitkn saham. Artinya nilai yang terdapat di penilaian kinerja saham adalah cerminan dari nilai perusahaan yang di apresiasi oleh pasar. Penilaian terebut menggunakan nilai saham yang sedang berdar pada pasar modal, sedangkan kinerja perusahaan dapat dinilai dari return saham yang diperolehnya dalam satu periode tertentu. Selain menilai kinerja perusahaan, return saham juga dapat digunakan oleh para investor untuk menilai kinerja saham sebelum akhirnya menetapkan pilihan untuk membeli saham atau tidak. Kinerja perusahaan biasanya dinilai oleh para investor baik investor jangka panjang maupun jangka pendek.

Dalam menilai saham terdapat tiga metode yakni nilai buku, nilai pasar dan nilai instrisik. Nilai buku merupakan nilai yang dihitung berdasarkan pada pembukuan perusahaan penerbitan saham. Nilai pasar adalah nilai pada saham di pasar yang ditunjukkan oleh harga saham itu sendiri dan nilai intrisik adalah nilai yang sering dikenal dengan nilai teoritis, nilai yang sebenarnya dan nilai yang seharusnya terjadi dan terdapat pada nilai saham tersebut. ${ }^{16}$

\section{Volatilitas Harga Saham}

Pergeseran indikator nilai dan harga serta posisi untuk melakukan membuka nilai mata uang dan menutup nilai mata uang dalam indexs saat memberikan imbalan atau sistem (return) pada saat memantau dan melakukan transaksi dan mengukur perkembangan harga serta pergeseran nilai jual-beli saham pada pasar modal biasanya mengalami pergeseran dalam kurva indikator nilai jual-beli yang berada pada posisi selalu berubah dimana dalam kurva nilai jual-beli pada posisi nilai kurva positif atau (positive value) bahkan berada pada posisi negative, untuk memahami pergereran kurva dan indikator dalam indexs saham sejauh mana tingkat berpengaruh pergeseran nilai yang bersifat fluktuatif dan dinamis yakni dapat berbah-ubah dalam sekala waktu yang tidak tentu untuk mengetahui besar kecilnya pergeseran nilai kurva yang bersifat fluktuatif maka dapat diketauhi dan di lacak dari indkator pada nilai dan harga jual-beli saham dimana posisi nilai membuka mata uang dan menutup nilai mata uang. ${ }^{17}$ Pergeseran nilai dala kurva harga jual saham

\footnotetext{
${ }_{15}$ Mardani, Ayat-ayat dan Hadist Ekonomi Syariah. Edisi 1, cet 1 (Jakarta: PT. Radja Gravindo Persada, 2011), 70.

${ }^{16}$ Eduardus, "Portofolio dan Investasi teori dan aplikasi."

${ }^{17}$ Fahmi, Irham dan Yovi, Lavianti Hadi. 2009. Teori Portopolio dan Analisis Investasi Teori Tanya Jawab dan Soal Jawab. (Bandung: Alfabeta). 80.
} 
merupakan suatu yang tidak bisa diukur dan di lacak atau pun di ketahui secara tepat dan akurat maka dapat di ilustrasikan bahwasanya nilai dalam kurva indexs harga jual saham merupkan perkiraan dan taksiran. Proses penganalisiaan dalam study pada niai indexs saham yang bersifat fluktuatif dilakukan dengan cara penaksiran dengan cara analisa angka atau stastistka dalam mengamati dinamika pergeseran indexs haraga saham saat posisi membuka penawaran dan menutup penawaran baik nilai dan harga inex saham pada pasar modal lokal maupun perekonomian dan perkembangan pasar modal internasional. ${ }^{18}$ Firmansyah (2006). Pergeseran nilai jual nilai beli pada indikator kurva pada indexs aharga saham yang fluktuatif dapat di representasikan menggunakan model kuntitatif diamana dengan menganalisa dengan simpangan baku dimana merupakan bakuan standar defriasi yang sering juga desebut risiko dengan perhitungan dari prakiraan pergeseran kurva secara fluktuatif semakin tinggi naijual atau pun beli saham atau sebaliknya semakin rendah niali jual dan niali beli saham maka keuntungan yang apat di kembalikan sangat bergantung kepada pergeseran kurva maka niali ketidakpastian sangan pengembalian dan pemberin keuntungan tergantung kepada nilai dan harga pada indexs saham atau risiko pergeseran niali aman dari sebuah obligasi atau surat hutang yang berada pada saham. ${ }^{19}$

$\mathrm{H}_{\mathrm{a}} 1$ : terdapat perbedaan antara resiko saham syariah dan konvensional

$\mathrm{H}_{2} 2$ : terdapat perbedaan antara return saham perusahaan syariah dan konvensional

$\mathrm{H}_{\mathrm{a}} 3$ : terdapat perbedaan antara kinerja saham perusahaan syariah dan konvensional

$\mathrm{H}_{\mathrm{a}} 4$ : volatilitas harga saham syariah dan konvensional model GARCH. ${ }^{20}$

\section{Metode Penelitian}

Penelitian ini menggunakan data kuantitatif, ${ }^{21}$ bersifat cross section berupa harga close saham bulanan perusahaan yang terdaftar di JII dan LQ 45 periode 2016-2018. Penelitian ini menggunaan sumber data sekunder yaitu laporan keuangan periode 2016-2018 dari JII dan LQ 45 didapat dari website seputar forex. Sedangkan data Index JII dan LQ 45 didapat dari website dunia investasi. ${ }^{22}$

Peneliti menggunakan populasi seluruh perusahaan yang terdaftar di JII untu kelompok saham syariah dan LQ 45 untuk kategori konvensional periode 2016-2018. Metode pengambilan sampel yang diguakan adalah purposive sampling, dimana populasi yang

\footnotetext{
${ }^{18}$ Ricky Dwi Budi Harsono, "Konkordansi Model-Model Standard Volatilitas Harga Saham | Pusat Data Ekonomi \& Bisnis,” diakses 29 Desember 2020, http://pdeb.fe.ui.ac.id/?p=8908.

19 Tavinayati, Yulia Qamariyanti, dan Indonesia, Hukum pasar modal di Indonesia (Jakarta: Sinar Grafika, 2009), 50 .

${ }^{20}$ Yun Hariadi dan Yohanes Surya, "Kulminasi Prediksi Data Deret Waktu Keuangan Volatilitas dalam GARCH (1,1)," Departmental Working Paper (Bandung Fe Institute, Juni 2003), https://econpapers.repec.org/paper/bfewpsbfi/wpf2003.htm.

${ }^{21}$ Sujarweni Wiratna, "Metodologi Penelitian Bisnis dan Ekonomi," PT Pustaka Baru, Cetakan pertama, 2015, 32.

22 Maya Wulan Fitriani, “Analisis perbandingan risk dan return antara saham syariah dengan saham konvensional: Studi pada saham JII dan LQ45 pada sektor industri barang konsumsi” (PhD Thesis, Universitas Islam Negeri Maulana Malik Ibrahim, 2012).
} 
dijadikan sampel penelitian adalah populasi yang memenuhi kriteria sampel tertentu. Kriteria yang digunakan adalah sebagai berikut:

Tabel 2. Kriteria Pemilihan Sample Perusahaan Syariah dan Konvensional

\begin{tabular}{clc}
\hline No & Kriteria Pemilihan Sample Perusahaan Syariah & Jumlah \\
\hline 1 & Perusahaan tercatat di JII periode 2016-2018 & 45 \\
\hline 2 & $\begin{array}{l}\text { Perusahaan yang mempublikasikan laporan } \\
\text { keuangannya periode 2016-2018 }\end{array}$ & 45 \\
\hline 3 & Perusahaan yang memiliki data tidak lengkap & 2 \\
\hline & Jumlah perusahaan yang memenuhi kriteria & 43 \\
\hline 1 & Perusahaan tercatat di LQ 45 periode 2016-2018 & 58 \\
\hline 2 & $\begin{array}{l}\text { Perusahaan yang mempublikasikan laporan keuangan } \\
\text { perode 2016-2018 }\end{array}$ & 58 \\
\hline 3 & Perusahaan yang memiliki data tidak lengkap & 56 \\
\hline
\end{tabular}

Tekhnik analisis data yang dipilih oleh penelitiadalah sebagai berikut: 1) Menghitung rasio keuangan yang ditentukan dalam penelitian ini (return realisasi, expected return, resiko dan kinerja saham. 2) uji normalitas menggunakan One-Sample Kolmogorov Smirnov Test dengan tingkat sig. $5 \%$. Pengujian normalitas ini di maksudkan untuk mengetahui apakah data berdistribusi normal atau tidak dan juga sebagai bahan pertimbangan dalam menentukan jenis alat analisis yang digunakan untu melakukan uji beda (parametric atau non parametric) menggunakan SPSS for windows seri 20.3 ). Uji homogenitas dimaksudkan untuk mengetahui varian dari beberpa variasi mempunyai kesamaan atau tidak dengan dasar penilaiannya ${ }^{23}$ sebagai berikut: 1 . Jika nilai Sig. atau nilai probabilitas $<$ 0,05 maka dikatakan bahwa varian dari dua atau lebih kelompok populasi data adalah tidak sama. 2. Jika nilai Sig. atau nilai probabilitas $>0,05$ maka dapat dikatakan bahwa varian dari dua atau lebih kelompok poulasi adalah sama. 3. Uji beda masing masing variable antara return, resiko dan kinerja perusahaan saham syariah dan konvensional secara parsial dan simultan dengan menggunakan uji-t dua sample berpasangan untuk data berdistribusi normal dan uji mann-whitney untuk data yang berdistribusi tidak normal. Analisis volatilitas dalam penelitian ini dimulai dengan membuat time series plot dan menghitung statistic deskriftif masing masing saham dengan bantuan program eviews 9. 4. Selanjutnya dalam penerapan model GARCH dengan menggunakan harga penutupan Index JII dan Index LQ 45 dilakukan Uji Unit Root untu hasil data yang stationer langsung dilakukan penentuan ordo ARIMA metode Box- Jenkins, sedangkan data yang tidak stationer dilakukan differencing terlebih dahulu. Dasar penilaian data dikatakan stationer apabila nilai ADF statistic lebih besar dari Mackinon Critical Vallue 1\%, 5\% dan 10\% serta nilai probabilitasnya signifikan dibawah 10\%. 5. Uji ARCH-LM untuk mengetahui efek GARCH,jika data bersifat heteroskedastisitas maka dilakukan estimasi GARCH namun jika data bersifat Homoskedastisitas maka penelitian selesai. Hal

\footnotetext{
${ }^{23}$ Sugiyono, Statistika Untuk Penelitian (Bandung: Alfabeta, 2013), 20.
} 
ini dikarenakan salah satu syarat estimasi GARCH yaitu data harus bersifat heteroskedastisitas.

\section{Hasil dan Pembahasan}

\section{Uji Normalitas dan Uji Homogenitas}

Sebelum uji beda independetd Sample T-test dilakukan uji normalitas dan uji homogenitas sebagai syarat uji beda. Data yang digunakan dalam penelitian ini berjumlah lebih dari 30, sehingga menggunakan uji normalitas dengantipe uji kolmogorof smirnov. Dengan ketentuan jika hasil data $>0,05$ maka dinyatakan normal.

Tabel 3. Hasil Uji Normalitas Resiko Perusahaan Syariah dan Konvensional

\begin{tabular}{ccccc}
\hline $\begin{array}{c}\text { Uji Normalitas } \\
\text { Resiko }\end{array}$ & Mean & $\begin{array}{c}\text { Standar } \\
\text { Deviation }\end{array}$ & $\begin{array}{c}\text { Kolmogorov } \\
\text { Smirnov Z }\end{array}$ & $\begin{array}{c}\text { Asymp.Sig. (2- } \\
\text { tailed) }\end{array}$ \\
\hline Konvensional & 3349261581.5 & 2627996419 & 1.874 & 0,003 \\
\hline Syariah & 3384201283.8 & 2636177734 & 1.843 & 0,002 \\
\hline
\end{tabular}

Sumber: Data diolah, 2019

Berdasarkan tabel 3 yang menunjukkan bahwa, hasil uji normalitas resiko perusahaan syariah menunjukkan nilai Sig. $<$ nilai $\alpha$ dengan nilai signifikansi $0,002<0,05$. Begitupula dengan hasil uji resiko perusahaan konvensional yangmenunjukkan tingkat Sig $<0,05$ yaitu sebesar 0,003. Maka dapat disimpulkan bahwa resiko saham syariah dan konvensional berdistribus tidak normal.

Tabel 4. Hasil Uji Normalitas Return Perusahaan Konvensional dan Syariah

\begin{tabular}{ccccc}
\hline $\begin{array}{c}\text { Uji Normalitas } \\
\text { Return }\end{array}$ & Mean & $\begin{array}{c}\text { Standar } \\
\text { Deviation }\end{array}$ & $\begin{array}{c}\text { Kolmogorov- } \\
\text { Smirnov Z }\end{array}$ & $\begin{array}{c}\text { Asymp. } \\
\text { Sig. (2- tailed) }\end{array}$ \\
\hline Konvensional & 1383040 & 887954705 & 3.440 & 0.000 \\
\hline Syariah & 1302771 & 872196323 & 3.066 & 0.000
\end{tabular}

Sumber: Data diolah, 2019

Berdasarkan tabel diatas menunjukkan hasil Sig. return perusahaan syariah lebih besar dari $\alpha$ maka dapat disimpulkan bahwa, return investasi perusahaan syariah berdistribusi secara normal, sedangan return perusahaan konvensional berdistribsi tidak normal karna nilai berada di bawah nilai $\alpha$.

Tabel 5. Hasil Uji Normalitas Kinerja Saham Perusahaan Konvensional dan Syariah

\begin{tabular}{ccccc}
\hline $\begin{array}{c}\text { Uji Normalitas } \\
\text { Return }\end{array}$ & Mean & $\begin{array}{c}\text { Standar } \\
\text { Deviation }\end{array}$ & $\begin{array}{c}\text { Kolmogorov- } \\
\text { Smirnov Z }\end{array}$ & $\begin{array}{c}\text { Asymp.Sig. (2- } \\
\text { tailed) }\end{array}$ \\
\hline Konvensional & 138304002.964 & 887954705.1 & 3.440 & 0.000 \\
\hline Syariah & 130277138.759 & 872196323.6 & 3.066 & 0.000 \\
\hline
\end{tabular}

Sumber : Data diolah, 2019 
Berdasarkan tabel 5 menunjukkan hasil uji normalitas kinerja sahamperusahaan syariah menunjukkan nilai signifikan lebih besar dari $\alpha$ sebesar 0,794 hal ini tidak berbeda jauh dengan kinerja saham perusahaan konvensional sebesar 0,831 oleh karna itu dapat disimpulkan bahwakinerja saham syariah dan konvensional berdistribusi normal.

Tabel 6. Hasil Uji Homogenitas

\begin{tabular}{ccccc}
\hline & Levene Statistic & dfl & df2 & Sig \\
\hline Risiko & .015 & 1 & 295 & .901 \\
\hline Return & .019 & 1 & 295 & .891 \\
\hline Kinerja & .165 & 1 & 295 & .685
\end{tabular}

Sumber : Data diolah, 2019

Berdasarkan hasil uji homogenitas 3 variabel (return, resiko dan kinerja) perusahaan syariah dan konvensional beradadiatas nilai $\alpha$. Dengan demikian dapat dinyataan bahwa resiko return dan kinerja perusahaan syariah dan konvensional bersifat homogen.

\section{Uji Beda Mann Whitney}

Dalam penelitian ini uji normalitas yang dilakukan menghasilkan beberapa variable berdistribusi tidak normal. Maka, peneliti menggunaan uji Mann- Whitney untuk pengujian hipotesis . hasil uji beda mann whitney resiko, return dan kinerja saham perusahaan konvensional dan syariah menunjukkan hasil sebagai berikut:

Tabel 7. Hasil Uji Beda Resiko, Return dan Kinerja Perusahaan Konvensional dan Syariah

\begin{tabular}{|c|c|c|c|c|}
\hline & $1 \mathrm{Uji}$ Beda & Prediksi & Sig. & Hasil Uji Hipotesis \\
\hline \multirow[t]{3}{*}{ Resiko } & Konvensional & \multirow{3}{*}{$\begin{array}{l}\text { Terdapat perbedaan } \\
\text { resiko perusahaan } \\
\text { konvensional dan } \\
\text { syariah }\end{array}$} & \multirow{3}{*}{$\begin{array}{l}0,045 \\
<0,05\end{array}$} & \multirow{2}{*}{$\begin{array}{l}\text { Terdapat perbedaan } \\
\text { signifikan antara resiko } \\
\text { syariah dan konvensional. }\end{array}$} \\
\hline & \multirow[t]{2}{*}{ Syariah } & & & \\
\hline & & & & $\begin{array}{l}\text { Ha1 diterima dan Ho1 } \\
\text { ditolak }\end{array}$ \\
\hline
\end{tabular}

\begin{tabular}{|c|c|c|c|c|}
\hline \multirow[t]{2}{*}{ Return } & Konvensional & \multirow{2}{*}{\multicolumn{2}{|c|}{$\begin{array}{l}\text { Terdapat perbedaan } \\
\text { resiko perusahaan } \\
\text { konvensional dan } \\
\text { syariah }\end{array}$}} & \multirow{2}{*}{$\begin{array}{l}\text { Tidak terdapat perbedaan } \\
\text { signifikan antara return } \\
\text { syariah dan konvensional } \\
\text { Ho2 diterima dan Ha } \\
\text { ditolak }\end{array}$} \\
\hline & Syariah & & & \\
\hline
\end{tabular}

\begin{tabular}{|c|c|c|c|c|}
\hline \multirow[t]{2}{*}{ Kinerja } & Konvensional & \multirow{2}{*}{$\begin{array}{l}\text { Terdapat perbedaan } \\
\text { resiko perusahaan } \\
\text { konvensional dan } \\
\text { syariah }\end{array}$} & \multirow{2}{*}{$\begin{array}{c}0,079 \\
>0,05\end{array}$} & \multirow{2}{*}{$\begin{array}{l}\text { Tidak terdapat perbedaan } \\
\text { signifikan antara kinerja } \\
\text { perusahaan syariah dan } \\
\text { konvensional Ha3 } \\
\text { ditolak dan Ho3 diterima }\end{array}$} \\
\hline & Syariah & & & \\
\hline
\end{tabular}

Sumber: Data diolah, 2019 


\section{Uji Volatilitas Model GARCH}

Setelah dilakukan uji normalitas dan uji homogenitas sebagai syarat melakukan uji beda atau T test.peneliti juga melakukan Uji Volatilitas Harga Saham dengan Metode GARCH. Langah yang dipakai dalam pengujian ini yaitu, data tersebut di gunakan sebagai memprediksikan data yang mengandung akar unit ataukah sebaliknya. Sedangan data time series dikatakan stationer apabila data diatas tidak mengandung akas unit ( unit root) dengan mean, variance dan covariance konstan sepanjang waktu.

Tabel 8. Hasil Uji Root Harga Penutupan Saham Perusahaan

\begin{tabular}{|c|c|c|}
\hline \multirow[t]{2}{*}{ Perusahaan } & \multicolumn{2}{|c|}{ Adf Test } \\
\hline & T Statistik & Prob \\
\hline Syariah & -2.297898 & 0,4240 \\
\hline Konvensional & -1.890530 & 0,6381 \\
\hline \multicolumn{3}{|l|}{ Sumber:Data diolah, 2019} \\
\hline \multicolumn{3}{|c|}{$\begin{array}{l}\text { Hasil pengujian stationer perusahaan syariah dan konvensional di atas dapat dilihat } \\
\text { bahwa nilai ADF statistic perusahaan syariahsebesar }-2.297898 \text { lebih kecil dari } \\
\text { mackinon } 1 \%, 5 \% \text { dan } 10 \% \text { dengan nilai probabilitas }>10 \% \text { yaitu sebesar } 0,42 \text {. } \\
\text { Sedangkan hasil uji stationer perusahaan konvensional mempunyai ADF statistic } \\
\text { sebesar }-1.890530 \text { lebih kecil dari mackinnon } 1 \%, 5 \% \text { dan } 10 \% \text { dengan nilai } \\
\text { probabilitas diatas } 10 \% \text { yaitu } 0,6381 \text {. Dengan hasil ini dapat disimpulkan bahwa data } \\
\text { perusahaan syariah dan konvensional masih mengandung akar unit, dengan kata lain } \\
\text { data tidak stationer. Maka akan dilakukan unit root tingkat first difference. }\end{array}$} \\
\hline \multicolumn{3}{|c|}{ Tabel 9. Hasil Uji Stationer First Different } \\
\hline \multirow[t]{2}{*}{ Perusahaan } & \multicolumn{2}{|c|}{ Adf test } \\
\hline & $\mathrm{T}$ & Prob \\
\hline Syariah & -4.432132 & 0.0013 \\
\hline Konvensional & -4.682715 & 0.0006 \\
\hline
\end{tabular}

Sumber:Data diolah, 2019

Hasil uji stationer firs different perusahaan konvensional menghasilkan nilai ADF statistic sebesar -4.682715 lebih besar dari mackinnon $1 \%, 5 \%$ atau $10 \%$ dengan nilai probabilitas sebesar 0,0006 lebihkecil dari 10\%. Dengan demikian dapatdisimpulkan bahwa data perusahaan konvensional sudah stationer. Karena hasil data termasuk pada difference 1, maka model yang digunakan yaitu model GARCH 91,1,0), GARCH 90,1,1) atau GARCH $(1,1,1)$.

Tabel 10. Estimasi Model GARCH

\begin{tabular}{cccc}
\hline \multicolumn{4}{c}{ Syariah } \\
\hline Model & Log Likehood & AIC & SC \\
\hline GARCH (1.1.1) & -173.7281 & 9.929337 & 10.14927 \\
\hline GARCH (1.0.0) & -161.4029 & 9.244607 & 9.464540 \\
\hline
\end{tabular}




\begin{tabular}{cccc}
\hline GARCH $(0.0 .1)$ & -161.3708 & 9.242820 & 9.462754 \\
\hline GARCH (1.1.0) & -158.4604 & 9.136686 & 9.400606 \\
\hline \multicolumn{4}{c}{ Konvensional } \\
\hline Model & Log Likehood & AIC & SC \\
\hline GARCH (1.1.1) & -156.0398 & 8.946656 & 9.166590 \\
\hline GARCH (1.0.0) & -170.9437 & 9.774652 & 9.994585 \\
\hline GARCH $(0.0 .1)$ & -175.0850 & 10.00472 & 10.22465 \\
\hline
\end{tabular}

Sumber : Data diolah, 2019

Hasil perhitungan di atas terlihat bahwa nilai log likehood terbesar serta nilai AIC dan SC terkecil dapat ditentukan model terbaik bagi perusahaan syariah adalah GARCH (1.1.0) dengan nilai log likehood nya sebesar -158,4604 dan angka AIC sebesar 9.136686 serta AC sebesar 9.400606 dan bagi perusahaan konvensional adalah GARCH (1.1.1) dengan nilai log likehood sebesar 156.0398 dan AIC diangka 8.946656 dan SC sebesar 9.166590.

Berdasarkan model GARCH selanjutnya model tersebut digunakan untuk memprediksi harga saham dimasa depan. Hasil predisi tersebut kan digunakan menggunakan MAPE (Mean Absolute Precentage Error).

Semakin kecil tingkat MAPE maka tingkat erroratauesalahan peramalan semakin kecil dan berarti tingkat ketepatan semakin tinggi. Maka hasil uji di jabarkan dalam tabel dibawah ini:

Tabel 11. MAPE Prediksi Harga Saham

\begin{tabular}{cc}
\hline Perusahaan & MAPE \\
\hline Syariah & 2.019305 \\
\hline Konvensional & 2.522283 \\
\hline
\end{tabular}

Sumber : Data diolah, 2019

Hasil evaluasi dari model GARCH sangat bagus, karena tingkat keakuratannya sangat tinggi yaitu kurang dari 5\%. Hal ini menunjukkan bahwa model GARCH dapat menjadi model prediksiyang tepat untuk meramalkan harga saham masa depan. Hasil perhitungan MAPE yang menunjukkan perusahaan syariah lebih kecil dari pada perusahaan konvensional dengan nilai2.019305dan MAPEkonvensional 2.522283. berdasarkan pada hasil data diatas maka peneliti dapat memberikan kesimpulan bahwa volatiloitas pada harga saham syariah dan convensionalyang diuji menggunakan model GARCH dapat dipastikan bahwa volatilitas harga saham syariah akan lebih rendah dibandingkam dengan saham konvensional.

\section{Pembahasan}

\section{a. Perbandingan Risiko Investasi Perusahaan saham Syariah dan Konvensional}

Dari hasil perbandingan resiko investasi perusahaan syariah dan konvesional dihasilkan nilai dengan uji mann whitney sebesar Sig. 0,04 < dari nilai $\alpha$. Maka disimpulkan bahwa Ho ditolak dan $\mathrm{Ha}$ diterima. Kesimpulan tersebut 
menyatakan terdapatperbedaan signifikan antara resiko saham perusahaan syariah dan konvensional. Hal ini bertolakbelakang dengan teori yang mengatakan bahwa "HIGH RISK HIGH RETURN" yang menyatakan bahwahipotesis penelitian ini diterima. Hasil ini menjadi kabar baik bagi para investor muslim yang tertarik berinvestasi di ranah perusahaan syariah yang menjanjikan return yang sama namun dengan kadar resiko yang lebih rendah dari perusahaan konvensional. Hasil ini juga selaras dengan prnyataan "hans Kwee, direktur investa mandiri mengatakan bahwa pasar saham syariah lebih gabus serta berkualitas dari pada konvensional. Beliau juga menyampaikan jika pasar saham syariah sudah melalui berbagai proses kelayakan yang diantaranya adalah proses screaning sehingga menjadikan para investor lebih aman dalam berinvestasi modalnya, karena saham syariah tidak mempunyai hutang yang sangat tinggi, sedangkan pada pasar saham konvensional juga memiliki hutang yang relatif tinggi serta rentan pada penekanan yang akan berimbas pada risiko saham sehingga akan berdampak pada harga saham perusahaan tersebut. Selaras dengan Ayu Lestari (2013) memberikan sebuah kesimpulan bahwa Risk pasar saham convensional lebih tinggi apabila dibandingkan dengan pasar saham syariah.

\section{b. Perbandingan Return Investasi Perusahaan Syariah dan Konvensional}

Hasil pengujian Mann Whitney untuk return investasi perusahaan syariah dan konvensional mendapatkan hasil sebesar 0,189 lebih besar dari nilai $\alpha$ yang berarti signifikan. Maka dapat diambil kesimpulan bahwa Ha2 di tolak dan Ho2 diterima. Dengan demikian tidak terdapat perbedaan yang cukup signifikan antara return investasi perusahaan syariah dan konvensional.

\section{c. Perbandingan Return Investasi Perusahaan Syariah dan Konvensional}

Setelah dilakukan pengujian Mann Whitney untuk menguji data-data kinerja pada pasar saham perusahaan syariah dan konvensional, maka dapat diambil kesimpulan bahwa Ha3 ditolak dan Ho3 diterima. Sehingga pada perbandingannya tidak memiliki perbedaan yang cukup signifikan antara risiko saham syariah dan konvensional.

\section{d. Volatilitas Harga Saham dengan Metode GARCH}

Dengan menggunakan model GARCH hasil yang ddapat sangat bagus, karena tingkat keakuratannya sangat tinggi yaitu kurang dari 5\%. Hal ini menunjukkan bahwa model GARCH dapat menjadi model prediksiyang tepat untuk meramalkan harga saham dimasa depan. Dari perhitungan MAPE perusahaan syariah lebih kecil disbanding MAPE perusahaan konvensional yaitu sebesar 2.019305 untukperusahaan syariah dan 2.522283 untuk perusahaan konvensional. Hasil ini menunjukkan bahwa dapat dipastikan volatilitas perusahaan syariah lebih rendah disbanding perusahaan konvensional

\section{Kesimpulan}

Setelah dilakukan penelitian perbandingan return, resiko investasi dan kinerja saham perusahaan dengan mengambil sampel sebanyak 43 perusahaan syariah dan 56 perusahaan konvensional dapat disimpulkan terdapat perbedaan signifikan antara resiko perusahaan syariah dan konvensional sedangkan untu variable return dan kinerja tidak 
ada perbedaan signifikan antara perusahaan syariah dan konvensional.

Volatilitas harga saham perusahaan syariah dan konvensional yang dihitung menggunakan metode GARCH menunjukan volatilitas harga saham syariah lebih rendah disbanding konvensional.

Bagi para investor di Indonesia sebaiknya mempertimbangkan untuk berinvestas di perusahaa berbasis syariah karena memiliki tingkat resiko yang lebih rendah di bandingkan dengan perusahaan konvensional. Kemudian peneliti selanjutnya sebaiknya menambahkan variable lain dengan menggunakan metode pusposive sampling agar dapat lebih banyak memakai sample dan menguji dengan metode yang berbeda.

\section{Daftar Pustaka}

Eduardus, Tandelilin. "Portofolio dan Investasi teori dan aplikasi." Yogyakarta: Kanisius, 2010.

Fitriani, Maya Wulan. "Analisis perbandingan risk dan return antara saham syariah dengan saham konvensional: Studi pada saham JII dan LQ45 pada sektor industri barang konsumsi." PhD Thesis, Universitas Islam Negeri Maulana Malik Ibrahim, 2012.

Hakim, Abdul. Analisis Investasi Edisi Revisi II. Jakarta: Salemba Empat, 2005.

Hariadi, Yun, dan Yohanes Surya. "Kulminasi Prediksi Data Deret Waktu Keuangan Volatilitas dalam GARCH (1,1)." Departmental Working Paper. Bandung Fe Institute, Juni 2003. https://econpapers.repec.org/paper/bfewpsbfi/wpf2003.htm.

Hariyani, Iswi, dan R. Serfianto Dibyo Purnomo. "Buku Pintar Hukum Bisnis Pasar Modal Strategi Tepat Investasi Saham.” Obligasi, Waran, Right, Opsi, Reksadana, \& Produk Pasar Modal Syariah, Transmedia Pustaka, Jakarta, 2010.

Harsono, Ricky Dwi Budi. "Konkordansi Model-Model Standard Volatilitas Harga Saham | Pusat Data Ekonomi \& Bisnis.” Diakses 29 Desember 2020. http://pdeb.fe.ui.ac.id/?p=8908.

Jogiyanto, Hartono M. "Teori portofolio dan analisis investasi." Edisi Ketujuh. BPFE. Yogyakarta, 2010.

Kasanah, Herni Ruliatul, dan Saparila Worokinasih. "Analisis Perbandingan Return dan Risk Saham Syariah dengan Saham Konvensional (Studi pada Jakarta Islamic Index (JII) dan IDX30 Periode 2014-2016)." Jurnal Administrasi Bisnis 58, no. 2 (2018): 46-55.

Mardani. Ayat-ayat dan Hadist Ekonomi Syariah. Edisi 1, cet 1. Jakarta: PT. Radja Gravindo Persada, 2011.

Maskur, Ali. "Volatilitas harga saham antara saham konvensional dan syariah." Dinamika Keuangan dan Perbankan 1, no. 2 (2009): 82-94.

Puspitasari, Ratih, dan Defani Pramesti. "Analisis Resiko Dan Tingkat Pengembalian Saham Terhadap Portofolio Optimal Saham (Studi Kasus Pada 8 Saham Dari LQ-45)," 1 Oktober 2011. 
Ramli, Anwar. "Risk dan return saham perusahaan industri barang konsumsi di bursa efek Indonesia." Jurnal Aplikasi Manajemen 8, no. 4 (2010): 1090-1097.

Rosyida, Ajeng Gama, dan Imron Mawardi. "Perbandingan Tingkat Pengembalian (Return), Risiko dan Koefisien Variasi pada Saham Syariah dan Saham Non Syariah di Bursa Efek Indonesia (BEI) Periode 2011-2013.” Jurnal Ekonomi Syariah Teori dan Terapan 2, no. 4 (2015).

Scott, David F. Basic Financial Management. Upper Saddle River: Prentice Hall, 1999.

Sugiyono. Statistika Untuk Penelitian. Bandung: Alfabeta, 2013.

Suryomurti, Wiku. “Super Cerdas Investasi Syariah.” Jakarta: Qultum Media, 2011.

Sutedi, Adrian. Pasar modal syariah: sarana investasi keuangan berdasarkan prinsip syariah. Rawamangun, Jakarta: Sinar Grafika, 2011.

Tavinayati, Yulia Qamariyanti, dan Indonesia. Hukum pasar modal di Indonesia. Jakarta: Sinar Grafika, 2009.

Wiratna, Sujarweni. "Metodologi Penelitian Bisnis dan Ekonomi." PT Pustaka Baru, Cetakan pertama, 2015. 